\title{
Rancang Bangun Alat Pembelah Buah Kakao (Theobroma cacao) Semi Mekanis
}

\author{
The Design of Semi-Mechanical Cacao (Theobroma cacao) Splitter \\ Hermawati, Program Studi Pendidikan Teknologi Pertanian Fakultas Teknik Universitas \\ Negeri Makassar, email: hermawati_tawil@yahoo.co.id \\ Jamaluddin, Program Studi Pendidikan Teknologi Pertanian Fakultas Teknik Universitas \\ Negeri Makassar, email: mamal_ptm@yahoo.co.id \\ Lahming, Program Studi Pendidikan Teknologi Pertanian Fakultas Teknik Universitas Negeri \\ Makassar, email: lahmingmaja@gmail.com
}

\begin{abstract}
Abstrak
Petani kakao pada umumnya melakukan pembelahan buah kakao satu per satu secara manual dengan alat pemukul, sabit, palu atau saling memukulkan buah yang satu dengan lainnya. Pembelahan secara manual membutuhkan waktu yang lama, kapasitas pembelahan yang sedikit dan memungkinkan resiko kecelakaan kerja yang relatif tinggi, sehingga perlu dilakukan rancang bangun alat pembelah buah kakao semi mekanis. Penelitian ini adalah penelitian rekayasa atau rancang bangun yang bertujuan untuk membuat dan menganalisis unjuk kerja alat pembelah buah kakao semi mekanis. Penelitian ini meliputi beberapa proses diantaranya, pembuatan setiap komponen, perakitan alat pembelah buah kakao hingga pengujian alat. Alat pembelah buah kakao yang dihasilkan bekerja dengan menggunakan sistem tekan (press). Pada proses pengoperasian alat ini, buah kakao akan mendapatkan tekanan dari komponen pembelah sampai terbelah atau terpecah. Proses pengujian alat menggunakan masing-masing 3 buah kakao untuk sekali tekan yang dilakukan sebanyak 10 kali ulangan. Hasil dari pengujian alat ini diperoleh rata-rata kapasitas efektif alat 1126 buah/jam, kerusakan hasil yaitu rata-rata biji rusak 2,4\%, biji tidak tersaring 57,8\% sehingga persentase biji utuh 97,6\% dan rata-rata persentase biji tersaring hanya $42,2 \%$, serta efisiensi $100 \%$. Berdasarkan hasil penelitian yang diperoleh, kapasitas kerja dengan menggunakan alat pembelah buah kakao semi mekanis ini meningkat dan dapat mengurangi resiko kecelakaan kerja dan kerusakan biji yang dihasilkan jika dibandingkan dengan pembelahan manual yang menggunakan pisau atau golok terutama untuk buah kakao yang mengalami kerusakan akibat serangan hama penggerek buah.
\end{abstract}

Kata Kunci: kakao; pembelah; rancang bangun; kulit buah

\begin{abstract}
Cocoa farmers generally split cacao one by one manually with a bat, sickle, hammer or hitting one another. Manual cleavage requires a long time, a small cleavage capacity and allows a relatively high risk of work accidents, so it is necessary to design and construct a semimechanical cacao splitter. This research was an research and development that aimed to make and analyze the performance of semi-mechanical cacao fruit splitter. This research includes several processes including making each component, assembling the cacao splitter and testing the tool. The resulting cacao splitter works by using a system of press. In the process of operating this tool, the cacao will get pressure from the splitting component until it is split. The testing process used 3 pieces of cacao for one press which was carried out 10 times. The
\end{abstract}


results of testing obtained an average effective capacity of 1126 pieces / hour, yield damage ie the average damaged seeds $2.4 \%$, unfiltered seeds $57.8 \%$ so that the percentage of whole seeds $97.6 \%$ and the average percentage only $42.2 \%$ filtered seeds, and $100 \%$ efficiency. Based on the results of the study, the working capacity obtained by using this semi-mechanical cacao fruit splitting tool increases and can reduce the risk of work accidents and damage to the beans produced when compared to manual cleavage using knives or machetes, especially for cocoa pods which are damaged due to fruit borer attack.

Keywords: cacao; splitter; building design; rind

\section{Latar Belakang}

Tanaman kakao (Theobroma cacao L.) merupakan famili sterculiaceae yang tumbuh baik pada iklim yang suhunya teratur dan cukup lembab. Kakao merupakan salah satu komoditi hasil perkebunan yang mempunyai peran cukup penting dalam kegiatan perekonomian di Indonesia. Kakao juga salah satu komoditas ekspor yang cukup penting sebagai penghasil devisa negara selain minyak dan gas. Indonesia merupakan negara produsen dan eksportir Kakao terbesar ketiga dunia setelah Ghana dan Pantai Gading (Badan Pusat Statistik, 2017).

Produksi kakao Indonesia pernah mencapai angka 838 ribu ton pada tahun 2010 (Ditjen Perkebunan 2014), akan tetapi pada tahun 2013 hingga 2016 mengalami penurunan sebesar 8,67\%. Tahun 2017 kembali mengalami penurunan $7 \%$ menjadi 657,1 ribu ton. Sulawesi yang merupakan salah satu sentra produksi utama kakao juga mengalami penurunan produksi dari 114,3 ribu ton menjadi 113,8 ribu ton yang $100 \%$ berasal dari perkebunan rakyat.

Permasalahan utama penyebab menurunnya produktivitas kakao diantaranya adalah tingginya serangan hama penyakit, pohon-pohon kakao yang telah tua, serta mutu dan kualitas biji kakao yang rendah (Munarso, 2016). Rendahnya mutu dan kualitas kakao ini dikarenakan penanganan pasca panen kakao belum dilakukan dengan baik dan benar sehingga kakao yang dihasilkan oleh petani masih tercampur dengan benda-benda asing, pengeringan kurang sempurna dan pembelahan kulit buah yang masih kurang efektif.

Pembelahan atau pemecahan kulit buah kakao merupakan kegiatan dalam pasca panen yang membutuhkan tenaga yang banyak sehingga sering mengalami penundaan karena keterbatasan kemampuan petani melakukan kegiatan ini.

Pembelahan buah kakao secara manual dengan alat pemukul, sabit, palu atau saling memukulkan buah yang satu dengan yang lainnya, waktu yang dibutuhkan lama, kapasitas pembelahan yang diperoleh sedikit serta kemungkinan resiko kecelakaan kerja yang ditimbulkan relatif tinggi. Rahman dkk., (2016) menyatakan bahwa seorang petani yang telah mahir memecah buah kakao hanya mampu memecah kurang lebih 800 buah per hari ditambah satu orang lagi tenaga kerja untuk mengeluarkan biji dari buah.

Teknologi atau mesin pemecah buah kakao canggih dan berkapasitas tinggi dengan sistem otomatis sebenarnya telah ada, akan tetapi hanya digunakan oleh perusahaan atau industri besar. Hal ini dikarenakan biaya yang sangat tinggi dan membutuhkan suatu ruang yang luas. Sehingga belum dapat dijangkau oleh sebagian besar petani kakao skala menengah ke bawah. 
Selain itu mesin teknologi canggih berkapasitas tinggi pada umumnya berukuran besar yang membutuhkan transportasi untuk pengangkutannya ke lokasi pemanenan kakao sehingga petani harus mengeluarkan biaya tambahan. Terutama lokasi lahan kakao yang berada di perbukitan, pengangkutannya akan lebih sulit. Oleh karena itu, dibutuhkan teknologi tepat guna untuk membantu petani dalam membelah buah kakao yang terjangkau, mudah dioperasikan dan praktis dibawa ke manapun. Wahyudi dkk., (2008) menyatakan bahwa dalam pembangunan pertanian tentu akan sangat berbeda dalam segi kepraktisan maupun hasil tani apabila petani tersebut mengadopsi teknologi dibandingkan ia memakai cara tradisional.

Berdasarkan uraian di atas, maka perlu dilakukan rancang bangun alat pembelah buah kakao semi mekanis untuk mengatasi salah satu masalah yang dihadapi petani pada proses penanganan pasca panen buah kakao.

\section{Tujuan Penelitian}

Adapun tujuan penelitian ini adalah sebagai berikut:

1. Untuk membuat alat pembelah buah kakao semi mekanis, dan

2. Untuk mengetahui alat yang dirancang memiliki unjuk kerja yang efektif dan efisien.

\section{Bahan dan Metode}

Metode yang digunakan pada penelitian ini adalah penelitian rekayasa, pada penelitian ini dilakukan pengujian kinerja alat pembelah buah kakao semi mekanis.

\section{Waktu dan Tempat}

Pembuatan dan pengujian alat dilaksanakan pada bulan Agustus-Oktober 2019. Alat ini dibuat dan dirakit di bengkel Salama dan pengujian dilaksanakan di Kebun Kelompok Tani Mattayang, Kabupaten Polewali Mandar, Sulawesi Barat.

\section{Desain Rancangan}

Gambar desain produk yang diperoleh dapat dilihat pada Gambar 1.

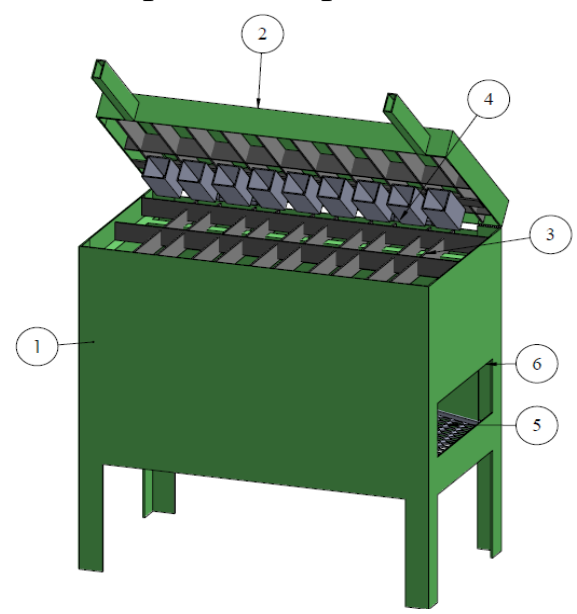

Gambar 1. Desain Rancangan Alat

Keterangan Gambar :

1. Rangka Utama

2. Rangka Penutup

3. Tempat Peletakan Buah

4. Pembelah/Pemecah

5. Saringan

6. Lubang Pengeluaran Kulit

\section{Alat dan Bahan}

Adapun alat-alat yang digunakan dalam perancangan alat pembelah buah kakao yaitu: mesin las listrik, mesin gerinda, mesin bor, mistar baja, gunting, spray gun, stopwatch. Sedangkan bahannya adalah besi siku $20 \mathrm{~mm}$ x $20 \mathrm{~mm}$ x $2 \mathrm{~mm}$, besi holo $40 \mathrm{~mm}$ x $40 \mathrm{~mm} \times 2 \mathrm{~mm}$ dan 35 $\mathrm{mm} \times 15 \mathrm{~mm} \times 1 \mathrm{~mm}$, baut dan mur, engsel 100 mm, elektroda Nikko steel RD260-2.0, cat besi, besi plat strip $33 \mathrm{~mm}$ x $4 \mathrm{~mm}$, tali diameter $1 \mathrm{~mm}$, seng plat $0,3 \mathrm{~mm}$. 


\section{Prosedur Penelitian}

Desain atau Perancangan

Pada tahap ini dilakukan pembuatan gambar desain dari alat yang akan dibuat. Desain alat dibuat menggunakan aplikasi Solidworks 2015 untuk memudahkan perancangan alat yang diinginkan.

\section{Analisis Rancangan Fungsional}

a. Rangka, berfungsi sebagai tempat menopang bagian - bagian alat secara keseluruhan. Rangka juga berfungsi sebagai dudukan dari suatu alat (Dahlan dkk., 2019)

b. Tempat peletakan buah, berfungsi sebagai tempat diletakkannya buah kakao sebelum dibelah.

c. Pembelah, berfungsi untuk membelah atau memecahkan kulit buah kakao.

d. Saringan, berfungsi untuk menyaring biji kakao yang telah dipecah dan terpisah dari kulit buahnya.

e. Lubang pengeluaran kulit, berfungsi sebagai tempat keluarnya kulit kakao yang telah terbelah.

\section{Analisis Rancangan Struktural}

\section{a. Rangka}

Rangka terdiri atas dua komponen yaitu rangka utama dan rangka penutup. Rangka utama berukuran 600 mm x 350 mm x 600 mm dengan panjang kaki rangka $200 \mathrm{~mm}$ menggunakan besi siku berukuran $20 \mathrm{~mm}$ x $20 \mathrm{~mm}$ dengan ketebalan $2 \mathrm{~mm}$. Rangka utama dapat dilihat pada Gambar 2.

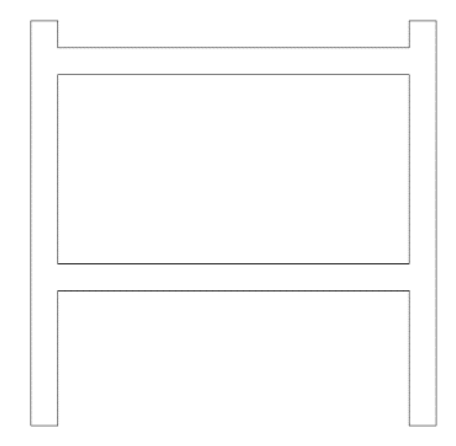

Gambar 2. Rangka Utama

Rangka penutup memiliki ukuran panjang dan lebar yang sama dengan rangka utama yaitu $600 \mathrm{~mm}$ x $350 \mathrm{~mm}$ serta tinggi $50 \mathrm{~mm}$ seperti pada Gambar 3.

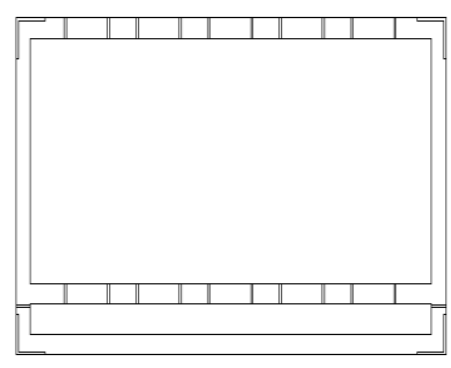

Gambar 3. Rangka penutup

b. Tempat Peletakan Buah

Tempat peletakan buah terdiri dari 12 batang besi strip dengan lebar $33 \mathrm{~mm}$, dan tebal $4 \mathrm{~mm}$ yang terbagi menjadi 10 batang berukuran panjang $350 \mathrm{~mm}$, dan 2 batang berukuran $600 \mathrm{~mm}$ yang terdapat pada rangka utama. Penempatan besi ini berjarak $50 \mathrm{~mm}$ antara besi satu dengan lainnya. Pada bagian penutup juga dibuatkan stan sama seperti bentuk tempat peletakan buah pada rangka utama sebagai tempat melekatnya pembelah. Tempat peletakan buah dapat dilihat pada Gambar 4. 


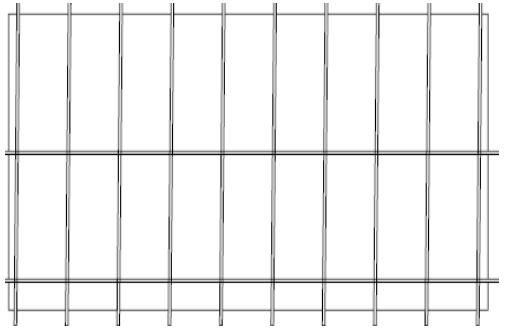

Gambar 4. Tempat Peletakan Buah

c. Pembelah atau Pemecah

Pembelah atau pemecah terbuat dari besi holo yang berukuran $40 \mathrm{~mm} \times 40 \mathrm{~mm}$ dengan ketebalan $2 \mathrm{~mm}$, sebanyak 9 dengan panjang $90 \mathrm{~mm}$ yang melekat tegak lurus secara horizontal pada besi strip yang panjangnya 600 yang akan dipasang di selasela stan yang terdapat pada bagian penutup (bagian atas). Kemudian ditambahkan tuas pegangan yang terbuat dari besi holo 35 mm x $15 \mathrm{~mm}$ dengan ukuran panjang 200 $\mathrm{mm}$. sehingga rangkaian pembelah secara keseluruhan dapat dilihat pada Gambar 5.

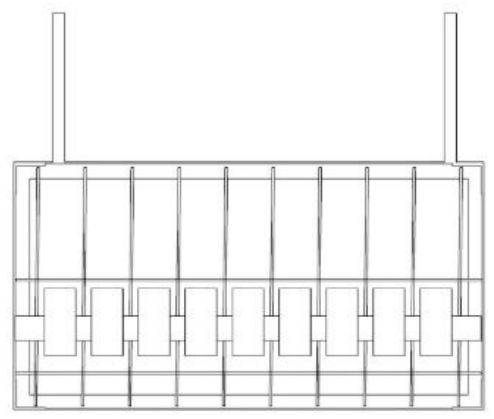

Gambar 5. Pembelah dan Tuas

Gaya beban yang dihasilkan oleh pembelah dapat diketahui dangan menghitung berat keseluruhan dari komponen pembelah dengan persamaan seperti yang digunakan oleh Maswira (2015) sebagai berikut:

$$
\mathrm{F}=\mathrm{m} \times \mathrm{g}
$$

Dengan, $\mathrm{F}=$ gaya beban $(\mathrm{N}), \mathrm{m}=$ massa (kg), dan $\mathrm{g}=$ percepatan gravitasi bumi $\left(9,81 \mathrm{~m} / \mathrm{s}^{2}\right)$

Massa dapat dicari dengan persamaan:

$$
\mathrm{m}=\mathrm{V} \times \rho
$$

Dengan, $\mathrm{m}=$ massa $(\mathrm{kg}), \mathrm{V}=$ volume $\left(\mathrm{m}^{3}\right)$, dan $\rho=$ berat jenis bahan $\left(\mathrm{kg} / \mathrm{m}^{3}\right)$

Volume yang dimaksud disini adalah volume dari semua komponen yang menjadi berat beban untuk menekan buah kakao. Volume dapat dihitung dengan persamaan berikut ini:

$$
\mathrm{V}=\mathrm{A} \times \mathrm{t}
$$

Dengan $\mathrm{V}=$ volume $\left(\mathrm{m}^{3}\right), \mathrm{A}=$ luas penampang $\left(\mathrm{m}^{2}\right)$, dan $\mathrm{t}=$ tinggi $(\mathrm{m})$

Pembelah terbuat dari besi holo yang berbentuk balok berongga sehingga volumenya dapat dihitung dengan persamaan:

$$
\mathrm{V}=\left(\mathrm{A}_{1}-\mathrm{A}_{2}\right) \times \mathrm{t}
$$

Dengan, $A_{1}=$ luas penampang luar/total $\left(\mathrm{mm}^{2}\right), \mathrm{A}_{2}=$ Luas penampang rongga $\left(\mathrm{mm}^{2}\right)$, dan $\mathrm{t}=$ tinggi $(\mathrm{m})$

Sehingga,

$$
\begin{aligned}
\mathrm{V}= & ([40 \mathrm{~mm} \times 40 \mathrm{~mm}]-[36 \mathrm{~mm} \times 36 \\
& \mathrm{mm}]) \times 90 \mathrm{~mm} \\
= & (1600 \mathrm{~mm}-1296 \mathrm{~mm}) \times 90 \mathrm{~mm} \\
= & 304 \mathrm{~mm}^{2} \times 90 \mathrm{~mm} \\
= & 27360 \mathrm{~mm}^{3}
\end{aligned}
$$

Karena jumlah pembelah ada 9, jadi volume pembelah adalah:

$$
\begin{aligned}
\mathrm{V} & =9 \times 27360 \mathrm{~mm}^{3} \\
& =246240 \mathrm{~mm}^{3}
\end{aligned}
$$

Volume stan atau tempat melekatnya pembelah, dapat dihitung dengan persamaan (3):

$$
\begin{aligned}
\mathrm{V} & =350 \mathrm{~mm} \times 33 \mathrm{~mm} \times 4 \mathrm{~mm} \\
& =46200 \mathrm{~mm}^{3}
\end{aligned}
$$

Stan pembelah terdiri dari 10 batang besi strip sehingga volumenya menjadi:

$$
\begin{aligned}
\mathrm{V} & =10 \times 46200 \mathrm{~mm}^{3} \\
& =462000 \mathrm{~mm}^{3}
\end{aligned}
$$


Volume 3 batang penyangga adalah:

$$
\begin{aligned}
& =3(600 \mathrm{~mm} \times 33 \mathrm{~mm} \times 4 \mathrm{~mm}) \\
& =3\left(79200 \mathrm{~mm}^{3}\right) \\
& =237600 \mathrm{~mm}^{3}
\end{aligned}
$$

Rangka penutup terdiri dari 4 penghubung besi strip yang berbeda ukuran dan 2 besi siku sehingga volumenya dapat dihitung sebagai berikut ini:

Volume penghubung besi strip:

$$
\begin{aligned}
\mathrm{V}= & 2(600 \mathrm{~mm} \times 33 \mathrm{~mm} \times 4 \mathrm{~mm})+2 \\
& (350 \mathrm{~mm} \times 33 \mathrm{~mm} \times 4 \mathrm{~mm}) \\
= & 2\left(79200 \mathrm{~mm}^{3}\right)+2\left(46200 \mathrm{~mm}^{3}\right) \\
= & 158400 \mathrm{~mm}^{3}+92400 \mathrm{~mm}^{3} \\
= & 250800 \mathrm{~mm}^{3}
\end{aligned}
$$

Volume penghubung besi siku dapat dihitung dengan persamaan (4):

$$
\begin{aligned}
\mathrm{V}= & 2([20 \mathrm{~mm} \times 20 \mathrm{~mm}]-[18 \mathrm{~mm} \times 18 \\
& \mathrm{mm}]) \times 450 \mathrm{~mm} \\
= & 2\left(76 \mathrm{~mm}^{2}\right) \times 450 \mathrm{~mm} \\
= & 68400 \mathrm{~mm}^{3}
\end{aligned}
$$

Jadi volume rangka penutup adalah:

$$
\begin{aligned}
\mathrm{V} & =250800 \mathrm{~mm}^{3}+68400 \mathrm{~mm}^{3} \\
& =319200 \mathrm{~mm}^{3}
\end{aligned}
$$

Volume dinding penutup yang terbuat dari seng plat $0,3 \mathrm{~mm}$ sehingga :

$$
\begin{aligned}
\mathrm{V}= & (600 \mathrm{~mm} \times 350 \mathrm{~mm} \times 0,3 \mathrm{~mm})+2 \\
& (600 \mathrm{~mm} \times 50 \mathrm{~mm} \times 0,3)+2(350 \\
& \mathrm{mm} \times 50 \mathrm{~mm} \times 0,3 \mathrm{~mm}) \\
= & 63000 \mathrm{~mm}^{3}+18000 \mathrm{~mm}^{3}+10500 \\
& \mathrm{~mm}^{3} \\
= & 91500 \mathrm{~mm}^{3}
\end{aligned}
$$

Volume tuas yang terdiri dari besi holo sehingga dapat dihitung dengan persamaan (4):

$$
\begin{aligned}
\mathrm{V} & =([35 \mathrm{~mm} \times 15 \mathrm{~mm}]-[33 \mathrm{~mm} \times 13]) \\
& \times 200 \mathrm{~mm} \\
& =\left(525 \mathrm{~mm}^{2}-429 \mathrm{~mm}^{2}\right) \times 200 \mathrm{~mm} \\
& =19200 \mathrm{~mm}^{3}
\end{aligned}
$$

Karena tuas pegangan ada 2 sehingga volume tuas adalah:

$$
\begin{aligned}
\mathrm{V} & =2 \times 19200 \mathrm{~mm}^{3} \\
& =38400 \mathrm{~mm}^{3}
\end{aligned}
$$

Jadi volume total beban penekan adalah:

$$
\begin{aligned}
\mathrm{V}= & 246240 \mathrm{~mm}^{3}+462000 \mathrm{~mm}^{3}+237600 \\
& \mathrm{~mm}^{3}+319200 \mathrm{~mm}^{3}+91500 \mathrm{~mm}^{3}+ \\
& 38400 \mathrm{~mm}^{3} \\
= & 1394940 \mathrm{~mm}^{3}
\end{aligned}
$$

Karena volume total telah diketahui, maka massa dapat dicari menggunakan persamaan (2) dengan berat jenis besi adalah $7850 \mathrm{~kg} / \mathrm{m}^{3}$ (Husnah dkk., 2019):

$$
\begin{aligned}
\mathrm{m} & =\mathrm{V} \times \rho \\
& =1394940 \mathrm{~mm}^{3} \times 7850 \mathrm{~kg} / \mathrm{m}^{3} \\
& =1394940 \times 10^{-9} \mathrm{~m}^{3} \times 7850 \mathrm{~kg} / \mathrm{m}^{3} \\
& =10950279000 \times 10^{-9} \mathrm{~kg} \\
& =10,95 \mathrm{~kg}
\end{aligned}
$$

Sehingga diperoleh gaya beban dengan menggunakan persamaan (1):

$$
\begin{aligned}
\mathrm{F} & =\mathrm{m} \times \mathrm{g} \\
& =10,95 \mathrm{~kg} \times 9,81 \mathrm{~m} / \mathrm{s}^{2} \\
& =107,4195 \mathrm{~kg} \mathrm{~m} / \mathrm{s}^{2} \\
& =107,42 \mathrm{~N}
\end{aligned}
$$

Berdasarkan penelitian yang dilakukan oleh Hidayat (2017), diketahui bahwa gaya maksimum yang dibutuhkan untuk memecahkan 1 buah kakao adalah sebesar $800 \mathrm{~N}$, sehingga gaya yang dibutuhkan untuk membelah 3 buah kakao pada rancangan alat ini adalah:

$$
\begin{aligned}
\mathrm{F} & =3 \text { buah } \times 800 \mathrm{~N} \\
& =2400 \mathrm{~N}
\end{aligned}
$$

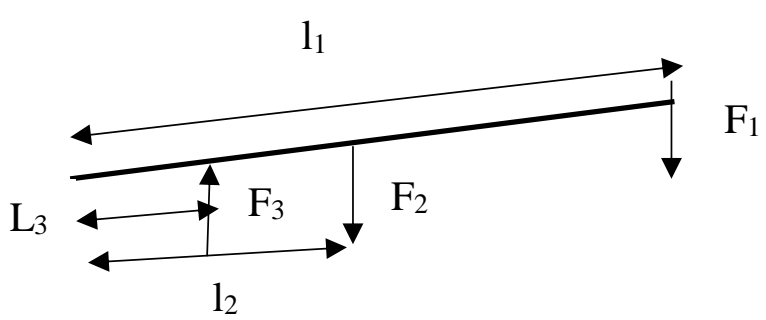


$\left(F_{1} \times 1_{1}\right)+\left(F_{2} \times 1_{2}\right)=F_{3} \times 1_{3}$

Dengan, $F_{1}=$ gaya operator pada tuas pembelah $(\mathrm{N}), \mathrm{F}_{2}=$ gaya beban $(\mathrm{N}), \mathrm{F}_{3}=$ gaya yang dibutuhkan alat $(\mathrm{N}), \mathrm{L}_{1}=$ panjang tuas pembelah $(\mathrm{mm}), \mathrm{L}_{2}=$ panjang titik berat ke pengungkit, dan $\mathrm{L}_{3}=$ panjang tuas ke pengungkit

Sehingga gaya yang akan digunakan operator adalah:

$\left(\mathrm{F}_{1} \times 550 \mathrm{~mm}\right)+(107,42 \mathrm{~N} \times 112,5 \mathrm{~mm})=$ $2400 \mathrm{~N} \times 50 \mathrm{~mm}$

$$
\begin{aligned}
\mathrm{F}_{1} & =\frac{120000 \mathrm{~N}-12084,75 \mathrm{~N}}{550} \\
& =\frac{107915,25}{550} \mathrm{~N} \\
& =196,21 \mathrm{~N}
\end{aligned}
$$

d. Saringan

Saringan memiliki ukuran $600 \mathrm{~mm}$ x $350 \mathrm{~mm}$. Lubang saringan berukuran diameter $20 \mathrm{~mm}$ dengan jumlah 390 lubang yang terbuat dari tali yang dianyam seperti jaring. Saringan dapat dilihat pada Gambar 6.

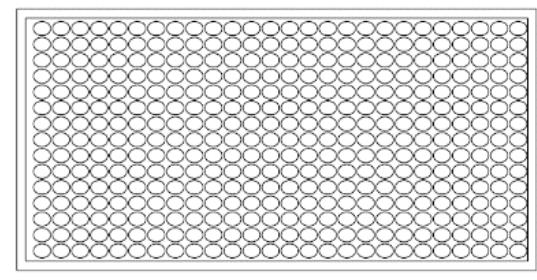

Gambar 6. Saringan

e. Lubang Pengeluaran Kulit

Lubang pengeluaran kulit dibuat dengan memberi lubang yang berukuran $300 \mathrm{~mm} \times 150 \mathrm{~mm}$ yang terletak pada dinding bagian samping alat seperti pada Gambar 7.

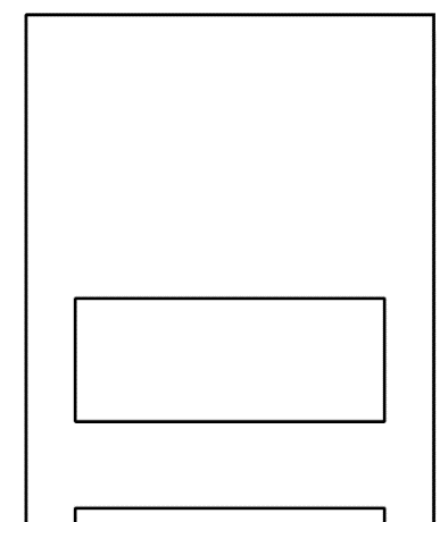

Gambar 7. Lubang Pengeluaran Kulit

Persiapan dan Pengadaan Alat dan Bahan

Setelah tahap perancangan selesai, selanjutnya mempersiapkan alat dan bahan yang dibutuhkan dalam pembuatan produk atau alat.

\section{Pembuatan Komponen Alat}

Pada tahap ini dilakukan pembuatan dan pemasangan komponen dasar alat sesuai dengan desain rancangan yang telah dibuat.

\section{Perakitan}

Tahap selanjutnya adalah merakit atau menggabungkan semua komponen yang telah dibuat menjadi satu kesatuan yang menghasilkan suatu produk yaitu alat pembelah kakao semi mekanis.

\section{Parameter Pengujian}

Untuk mengetahui unjuk kerja dari alat pembelah buah kakao yang telah dirancang, maka dilakukan perhitungan diantaranya adalah kapasitas efektif alat, rendemen, dan efektifitas alat dengan menggunakan rumus persamaan Maswira (2015) sebagai berikut: 
Kapasitas Efektif Alat (KEA)

Kapasitas efektif alat menunjukkan output maksimum pada tingkat operasi tertentu, sehingga dapat dihitung dengan rumus sebagai berikut:

KEA: $\frac{\text { Jumlah Buah Kakao dibelah }}{\text { Waktu yang dibutuhkan }}($ buah/jam)(1)

Persentase Keberhasilan dan Kerusakan Alat

Persentase keberhasilan dan kerusakan alat dapat dilihat dari efektivitas pembelah dan saringan.

\section{1) Efektivitas Pembelah}

$$
\begin{aligned}
& \text { PBR: } \frac{\text { Jumlah Biji Rusak }}{\text { Total Biji Kakao }} \times 100 \% \\
& \text { PBU }=\frac{\text { Jumlah Biji Utuh }}{\text { Total Biji Kakao }} \times 100 \%
\end{aligned}
$$

Dengan, PBR: Persentase Biji Rusak (g) dan PBU: Persentase Biji utuh (g).

2) Efektivitas Saringan

$$
\mathrm{PBT}=\frac{\text { Jumlah Biji Tersaring }}{\text { Total Biji Kakao }} \times 100 \%
$$

PBTT $=\frac{\text { Jumlah Biji idak Tersaring }}{\text { Total Biji Kakao }} \times 100 \%(\mathbf{9})$

Dengan, PBT: Persentase Biji Tersaring (g) dan PBTT: Persentase Biji Tidak Tersaring (g).

\section{Efisiensi}

Tujuan perhitungan efisiensi pembelahan yaitu untuk menentukan hasil bersih yang diperoleh dari kinerja alat yang digunakan.

$$
E=\frac{\text { Jumlah Buah Kakao yang Terbelah }}{\text { Total Buah Kakao }} \times 100 \%
$$

\section{Hasil dan Pembahasan}

\section{Deskripsi Produk yang Dihasilkan}

Alat pembelah buah kakao semi mekanis telah dibuat berdasarkan gambar desain produk yang telah dirancang. Alat ini menggunakan sistem tekan (press) yang dioprasikan oleh satu orang. Adapun alat yang dihasilkan dapat dilihat pada Gambar 8.

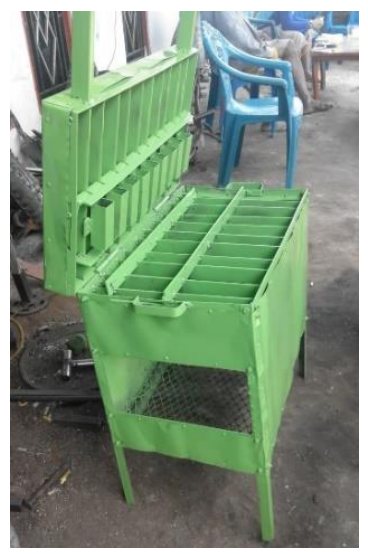

Gambar 8. Alat Pembelah Buah Kakao Semi Mekanis

Alat yang dihasilkan memiliki ukuran 600 $\mathrm{mm}$, lebar $350 \mathrm{~mm}$, dan tinggi $650 \mathrm{~mm}$ yang terdiri dari beberapa komponen utama yang dirakit menjadi satu-kesatuan sehingga terbentuk alat pembelah buah kakao semi mekanis yang dapat digunakan.

\section{Pembuatan Rangka}

Rangka terbuat dari besi siku berukuran $20 \mathrm{~mm} \times 20 \mathrm{~mm} \times 2 \mathrm{~mm}$ dan besi strip. Proses pembuatan rangka dimulai dengan melakukan pengukuran dan pemberian tanda pada besi kemudian dilakukan proses pemotongan. Menurut Djasba S. dkk., (2018), pengukuran dan pemberian tanda agar rangka memiliki tingkat presisi sesuai dengan ukuran yang diinginkan.

Jumlah potongan terdiri dari 18 potong dengan beberapa ukuran potongan. Potongan rangka terbagi 2 yaitu potongan rangka utama dan rangka penutup. Rangka utama terdiri dari 8 potong besi siku dan 4 potong besi strip. Sementara untuk rangka penutup terdiri dari 2 besi siku dan 4 besi strip. Pada rangka utama 6 potong besi siku 
berukuran $600 \mathrm{~mm}$ yang terbagi menjadi 4 potong yang digunakan sebagai tiang, dan 2 potong digunakan sebagai penghubung tiang. Sedangkan besi strip digunakan sebagai penghubung dan penyangga tempat peletakan buah kakao, 2 potong berukuran $600 \mathrm{~mm}$ dan 2 lainnya memiliki ukuran 350 $\mathrm{mm}$. Rangka penutup terdiri dari 2 potong besi siku berukuran $450 \mathrm{~mm}$, dan 2 potong besi strip berukuran $600 \mathrm{~mm}$ dan 2 potong lainnya berukuran $350 \mathrm{~mm}$.

Proses selanjutnya yaitu pengelasan dengan menghubungkan semua bagian potongan besi menjadi satu rangkaian rangka menggunakan las listrik. Menurut Arhamsyah (2018), tahap pengelasan dilakukan untuk menguatkan sambungan pada rangka. Pada rangka penutup besi siku yang digunakan dilakukan penekukan membentuk sudut $90^{\circ}$ pada masing-masing ujungnya sepanjang $50 \mathrm{~mm}$, sehingga lebar rangka menjadi $350 \mathrm{~mm}$. Selanjutnya keduanya dihubungkan dengan besi strip berukuran $600 \mathrm{~mm}$ dan $350 \mathrm{~mm}$ pada ujung besi.

\section{Pembuatan Tempat Peletakan Buah}

Pada rangka ditambahkan tempat peletakan buah yang terbuat dari besi strip berukuran panjang $350 \mathrm{~mm} \times 33 \mathrm{~mm} 10$ batang dan $600 \mathrm{~mm} \times 33 \mathrm{~mm}$ sebanyak 2 batang dengan ketebalan $3 \mathrm{~mm} .10$ batang besi potongan pendek dipasang secara horizontal dan membujur serta berjarak 6 $\mathrm{mm}$ dan $4 \mathrm{~mm}$ secara berselang. Sedangkan 2 batang besi potongan panjang dipasang secara horizontal dan melintang yang berguna sebagai penahan buah kakao agar dapat tertahan ketika mendapat tekanan dari pemecah serta berjarak $50 \mathrm{~mm}$ dari pinggir penyangga bagian belakang dan $125 \mathrm{~mm}$ dari potongan besi yang lainnya.

\section{Pembuatan Pembelah/pemecah}

Pembelah atau pemecah terbuat dari besi holo yang berukuran $4 \mathrm{~mm} \times 4 \mathrm{~mm}$ dengan ketebalan $2 \mathrm{~mm}$, sebanyak 10 dengan panjang $90 \mathrm{~mm}$ yang melekat tegak lurus secara horizontal pada besi strip yang panjangnya 600. Kemudian ditambahkan tuas penekan yang berfungsi sebagai pegangan ketika akan mengoprasikan alat tersebut. Tuas ini terbuat dari besi holo 15 $\mathrm{mm} \times 35 \mathrm{~mm}$ dengan panjang $20 \mathrm{~mm}$ sebanyak 2 batang.

\section{Pembuatan Saringan}

Saringan terbuat dari tali yang dibentuk seperti jaring yang lubangnya berukuran $20 \mathrm{~mm} \times 20 \mathrm{~mm}$. Saringan ini dipasang pada rangka utama penyangga bagian bawah.

\section{Lubang Pengeluaran Kulit}

Pembuatan lubang pengeluaran kulit kakao dilakukan dengan menggunting bagian dinding dari alat tersebut yang terbuat dari seng plat berukuran $0.3 \mathrm{~mm}$. Ukuran lubang pembuangan ini yaitu 30 $\mathrm{mm} \times 15 \mathrm{~mm}$ yang diberi penyangga pada bagian panjang dari besi strip.

\section{Proses Finalisasi}

Tahap finalisasi adalah tahap perangkaian atau pemasangan semua komponen alat yang telah dibuat mulai dari rangka, pembelah, saringan, dinding (lubang pengeluaran kulit) hingga pengecetan atau pemberian warna sehingga menjadi satu kesatuan alat sesuai letak fungsional dan strukturalnya. Proses ini berfungsi melihat komponen yang masih kurang untuk kemudian dilengkapi dan dilanjutkan pada uji coba alat. 


\section{Hasil Uji Coba}

Pengambilan data pemecah kulit buah kakao menggunakan alat ini dengan pengujian menggunakan masing-masing 3 buah kakao untuk setiap ulangan yang dilakukan sebanyak 10 kali. Data penelitian pengujian alat pembelah buah kakao ditunjukkan pada Tabel 1.

Tabel 1. Data Keseluruhan Pengujian Alat Pembelah Buah Kakao Semi Mekanis

\begin{tabular}{ccccccccc}
\hline Ulangan & $\begin{array}{c}\text { Jumlah } \\
\text { Buah }\end{array}$ & $\begin{array}{c}\text { Waktu } \\
\text { Pembelahan } \\
\text { (detik) }\end{array}$ & $\begin{array}{c}\text { Buah } \\
\text { Terbelah }\end{array}$ & $\begin{array}{c}\text { Total } \\
\text { Biji } \\
\text { (gram) }\end{array}$ & $\begin{array}{c}\text { Biji } \\
\text { Rusak } \\
\text { (gram) }\end{array}$ & $\begin{array}{c}\text { Biji } \\
\text { Utuh } \\
\text { (gram) }\end{array}$ & $\begin{array}{c}\text { Biji } \\
\text { Tersaring } \\
\text { (gram) }\end{array}$ & $\begin{array}{c}\text { Biji Tidak } \\
\text { Tersaring } \\
\text { (gram) }\end{array}$ \\
\hline 1 & 3 & 16 & 3 & 202 & 0 & 202 & 106 & 96 \\
2 & 3 & 13 & 3 & 186 & 4 & 182 & 63 & 123 \\
3 & 3 & 20 & 3 & 233 & 19 & 214 & 163 & 70 \\
4 & 3 & 15 & 3 & 182 & 7 & 175 & 88 & 94 \\
5 & 3 & 13 & 3 & 224 & 0 & 224 & 155 & 69 \\
6 & 3 & 11 & 3 & 158 & 0 & 158 & 25 & 133 \\
7 & 3 & 7 & 3 & 163 & 3 & 160 & 37 & 126 \\
8 & 3 & 6 & 3 & 217 & 13 & 204 & 95 & 122 \\
9 & 3 & 6 & 3 & 237 & 0 & 237 & 80 & 157 \\
10 & 3 & 7 & 3 & 220 & 5 & 215 & 73 & 147 \\
\hline Jumlah & $\mathbf{3 0}$ & $\mathbf{1 1 4}$ & $\mathbf{3 0}$ & $\mathbf{2 0 2 2}$ & $\mathbf{5 1}$ & $\mathbf{1 9 7 1}$ & $\mathbf{8 8 5}$ & $\mathbf{1 1 3 7}$ \\
Rata- & & $\mathbf{1 1 , 4}$ & $\mathbf{3}$ & $\mathbf{2 0 2 , 2}$ & $\mathbf{5 , 1}$ & $\mathbf{1 9 7 , 1}$ & $\mathbf{8 8 , 5}$ & $\mathbf{1 1 3 , 7}$ \\
rata & & & & & & & & \\
\hline Suta
\end{tabular}

Sumber : Hasil Analisis Data Penelitian

Kapasitas Efektif Alat

Perhitungan Besarnya kapasitas efektif alat diperoleh dari pembagian jumlah buah kakao yang dapat dibelah dengan waktu yang dibutuhkan. Rata-rata kapasitas efektif alat berdasarkan hasil penelitian yang diperoleh dari beberapa ulangan yaitu sebesar 1126 buah/jam.

Hasil kapasitas efektif alat didapatkan pada setiap ulangan berbedabeda, dengan kapasitas efektif terendah yaitu 540 buah/jam pada ulangan 3 dan tertinggi 1800 buah/jam pada ulangan 8 dan 9. Hal ini dikarenakan waktu yang dibutuhkan untuk memecahkan buah kakao juga berbeda-beda yang dipengaruhi oleh tingkat kekerasan kulit buah dan ukuran buah yang berbeda-beda. Semakin keras kulit buah maka semakin lama waktu dan tenaga yang dibutuhkan juga semakin tinggi. Semakin keras kulit buah maka semakin lama waktu dan tenaga yang dibutuhkan juga semakin tinggi. Begitu pula dengan ukuran buah, semakin kecil buah maka semakin cepat waktu yang dibutuhkan. Sejalan dengan pendapat Lingga dkk., (2014) bahwa perbedaan waktu disebabkan oleh tingkat kematangan buah, ukuran atau diameter yang berbedabeda dan kondisi fisik operator pada saat mengoperasikan alat.

Ukuran yang kecil memiliki luas penampang yang kecil sehingga tekanan yang diperoleh lebih besar. Oleh karena itu, waktu yang dibutuhkan sedikit, dengan demikian kapasitas alatnya pun semakin besar. Sedangkan tingkat kekerasan juga disebabkan adanya kerusakan pada buah 
akibat serangan hama penggerek buah, yang menyebabkan biji kakao mengeras dan menempel satu sama lain, ada pula yang menepel pada kulit buah. Sehingga mempengaruhi kekerasan kulit buah berdasarkan tingkat kerusakan yang ditimbulkan. Anna (2011) menyatakan buah yang terserang hama, kulit buah menjadi lebih keras sehingga sulit untuk memecahnya.

\section{Persentasi Keberhasilan Dan Kerusakan} Alat

Persentasi keberhasilan dan kerusakan dilihat dari efektivitas pembelah dan saringan yang ada pada alat. Efektivitas pembelah dapat ditentukan oleh seberapa banyak biji kakao yang rusak dan juga seberapa banyak biji kakao utuh dengan cara membagi jumlah biji kakao yang rusak atau utuh dengan total biji kakao dikali $100 \%$.

Kategori biji rusak yang dimaksud adalah biji kakao yang kulit bijinya terluka atau tergores oleh pemecah sehingga biji bagian dalam terlihat. Sementara itu, untuk efektivitas saringan ditentukan oleh seberapa banyak biji kakao yang dapat ataupun tidak tersaring dan terpisah dari kulit buah kakao yang telah dipecahkan dengan cara membagi jumlah biji tersaring atau tidak tersaring dengan total biji dikalikan $100 \%$. Biji yang tidak tersaring yang dimaksud adalah biji yang tertinggal diatas saringan dan menempel atau tidak terpisah pada kulit buahnya

Berdasarkan hasil penelitian yang diperoleh biji yang rusak terdapat pada ulangan 2, 3, 4, 7, 8, dan 10. Persentase biji rusak tertinggi sebesar $8,15 \%$ yaitu pada ulangan ke-3 sebanyak 19 g. Sedangkan persentase biji rusak terendah sebesar $0 \%$ atau tidak terdapat biji yang rusak sebanyak 4 ulangan yaitu pada ulangan 1, 5, 6 dan 9 .
Sehingga rata-rata persentase biji kakao yang rusak sebesar 2,42\% dan keberhasilan pemecah yang dilihat dari persentase biji utuh sebesar 97,58\%.

Efektivitas saringan dilihat dari persentase biji yang tersaring dan tidak tersaring. Rata-rata persentase biji tersaring sebesar 42,24\%, dengan persentase tertinggi $69,96 \%$ dan terendah sebesar $15,82 \%$ yaitu masing-masing pada ulangan ke-3 dan ke-1 sebaliknya dengan persentase biji kakao tidak tersaring. Sehingga diperoleh rata-rata persentase biji yang tidak tersaring sebesar $57,76 \%$. Hal ini dikarenakan pada sampel buah kakao yang digunakan terdapat buah yang mengalami kerusakan akibat hama penggerek, sehingga sebagian besar biji melekat pada kulit buah. Sejalan dengan penelitian yang dilakukan oleh Anna (2011) bahwa buah yang terserang penggerek buah kakao terlihat pada saat buah dipecah. Buah yang terserang PBK memiliki biji-biji berwarna cokelat kehitaman yang saling melekat Hal ini menyulitkan proses pengambilan biji kakao.

Faktor lain yang menyebabkan hal tersebut terdapat juga biji yang tidak terlepas dari plasentanya terutama, biji kakao yang belum matang sempurna (muda). Ikhsan (2013) menyatakan pada waktu muda, biji menempel pada bagian dalam kulit buah, tetapi saat masak biji akan terlepas dari kulit buah. Komponen utama buah kakao terdiri atas kulit, biji dan sisanya adalah plasenta yang mengikat $30-40$ biji (Martono, 2017).

\section{Efisiensi}

Efisiensi dapat dihitung dengan membagi buah kakao yang dapat dipecahkan dengan jumlah buah kakao yang dimasukkan sebelum dipecahkan dikali $100 \%$. Pada penelitian ini dilakukan 
10 kali ulangan dengan setiap ulangan terdapat 3 buah kakao yang dipecahkan sehingga jumlah keseluruhan buah kakao sebelum dipecahkan (masih utuh) yaitu sebanyak 30 buah, setelah dilakukan proses pemecahan semua buah kakao yang dimasukkan dapat dipecahkan, sehingga efisiensi yang diperoleh sebesar 100\%.

\section{Simpulan}

Berdasarkan hasil penelitian pada rancang bangun alat pembelah buah kakao (Theobroma cacao semi mekanis, dapat ditarik kesimpulan bahwa mekanisme kerja rancang bangun alat pembelah buah kakao semi mekanis meliputi pembuatan rangka, tempat peletakan buah kakao, pembelah atau pemecah, saringan dan pembuatan saluran pengeluaran kulit kakao. Setiap komponen tersebut masing-masing saling mendukung untuk digunakan dalam penanganan salah satu kegiatan pasca panen kakao. Prinsip kerja alat ini adalah sistem tekan (press) yang menggunakan tenaga manusia sebagai penggeraknya.

Alat pembelah buah kakao yang dirancang dapat digunakan dengan kapasitas efektif sebesar 1126 buah/jam, rata-rata persentase kerusakan biji hanya 2,42\% sehingga keberhasilan pembelahnya sebesar $97,58 \%$ serta efisiensi $100 \%$.

\section{Daftar Pustaka}

Anna, N. O. 2011. Pengelolaan panen dan pasca panen tanaman kakao (Theobroma Cacao L.) di Kebun Pt Rumpun Sari Antan 1, Cilacap, Jawa Tengah. (Skripsi). Bogor: Fakultas Pertanian IPB.

Arhamsyah, M., Syam, H., Jamaluddin, P. 2018. Modifikasi mesin pengering dengan memanfaatkan udara panas dari elemen pemanas listrik. Jurnal Pendidikan Teknologi Pertanian. 4: 196-208.

Badan Pusat Statistik. 2017. Statistik kakao Indonesia 2017. Jakarta: Badan Pusat Statistik.

Ditjen Perkebunan. 2014. Statistik perkebunan Indonesia 2013-2015; kakao. Jakarta: Direktorat Jenderal Perkebunan.

Dahlan, A. F. N., Sukainah, A., dan Jamaluddin, P. 2019. Rancang bangun alat pemanggang dange. Jurnal Pendidikan Teknologi Pertanian. 5(2): 76-82.

Djasba, S., Lahming, dan Jamaluddin, P. 2018. Modifikasi peredam suara (knalpot) mesin diesel traktor ramah lingkungan. Jurnal Pendidikan Teknologi Pertanian. 4: 49-58.

Hidayat, W., Asri, A., \& Kurniawan, E. 2017. Analisis tegangan geser, momen dan tegangan lentur maksimum untuk pembuatan pisau pada rancang bangun mesin pemecah buah kakao kapasitas 2 ton/jam. Seminar Nasional Penerapan Ilmu Pengetahuan dan Teknologi. Pontianak: Universitas Tanjung Pura.

Husnah, Darfia, N. E., dan Hidayat, F. 2019. Analisis struktur rangka baja ringan dan baja berat dengan aplikasi bricscad. Jurnal Teknik Sipil. 5(2):87-96.

Ikhsan, M. 2013. Hubungan antara tingkat kekerasan dan waktu pemecahan daging buah kakao (Theobroma Cacao L). (Skripsi). Makassar: Fakultas Pertanian Universitas Hasanuddin.

Lingga, N. E. P., Munir, A. P., Ichwan, N. 2014. Rancang bangun alat pengupas kulit nenas sistem press 
manual. Jurnal Rekayasa pangan dan Pertanian. 2(4): 110-116.

Martono, B. 2017. Karakteristik morfologi dan kegiatan plasma nutfah tanaman kakao. Bumga Rampai: Inovasi Teknologi Bioindustri Kakao.15-28.

Maswira, U. 2015. Rancang bangun alat pembelah buah pala (Myristica sp.) semi mekanis. (Skripsi). Padang: Fakultas Teknologi Pertanian. Universitas Andalas.

Munarso, S. J. 2016. Penanganan pascapanen untuk peningkatan mutu dan daya saing komoditas kakao. Jurnal Litbang Pertanian. 35(3):111-120.

Rahman, F., Darise, F., \& Djamalu, Y. 2016. Rancang bangun mesin pemecah buah kakao. Jurnal Teknologi Pertanian Gorongtalo (JTPG). 1(1): 95-104.

Wahyudi, T. R., Panggabean, dan Pujiyanto, 2008. Panduan lengkap kakao. Jakarta: Penebar Swadaya. 
Halaman ini sengaja dikosongkan 